\title{
PENGARUH VARIASI SUHU PENGERING TERHADAP MUTU DENDENG IKAN LELE DUMBO (Clarias gariepinus)
}

\author{
Muhammad Ikhsan 1), Muhsin2), Patang ${ }^{3)}$ \\ ${ }^{1}$ Alumni Program Studi Pendidikan Teknologi Pertanian \\ ${ }^{2}$ dan ${ }^{3}$ Dosen PTP FT UNM \\ insanlojo@gmail.com
}

\begin{abstract}
The aims of this research is to know the quality of chemical and hedonik Catfish jerky. This research used a completely randomized design (CRD) with 3 treatment drying temperature of $60^{\circ} \mathrm{C}, 65^{\circ} \mathrm{C}$ and $70^{\circ} \mathrm{C}$. The observed parameters is moisture, protein, fat content and quality hedonik catfish jerky. The results showed a drying temperature of $65^{\circ} \mathrm{C}$ is the best treatment with moisture content $25,02 \%$, protein $16,04 \%$, fat content $39,54 \%$, hedonik color 3.88, hedonik texture 3.77, hedonik aroma 3.75 and hedonik sense of 3.80.
\end{abstract}

\section{Key Words: Temperature, Catfish jerky, Quality, Cabinet Dryer}

\section{PENDAHULUAN}

Ikan merupakan salah satu sumber protein hewani yang banyak dikonsumsi masyarakat, mudah didapat, dan harganya murah. Namun ikan cepat mengalami proses pembusukan dan penurunan mutu dikarenakan daging ikan mempunyai kadar air yang tinggi, $\mathrm{pH}$ netral, teksturnya lunak, dan kandungan gizinya tinggi sehingga menjadi medium yang sangat baik untuk pertumbuhan bakteri (Hadiwiyoto, 1993). Saat ini, kurang lebih seperempat bagian dari ikan yang dikonsumsi oleh penduduk dunia adalah berasal dari budidaya dan persentase ini akan terus meningkat, sementara produk hasil tangkapan dari laut dan danau akan terus menurun disebabkan overfishing dan kerusakan lingkungan (Kurnia 2006).

Potensi perikanan budidaya secara nasional diperkirakan 15,59 juta hektar (ha) yang terdiri potensi air tawar 2,23 juta ha, air payau 1,22 juta ha dan budidaya laut 12,14 juta ham, sedangkan pemanfaatannya hingga saat ini masing masing baru $10,1 \%$ untuk budi daya air tawar, $40 \%$ pada budi daya air payau dan $0,01 \%$ untuk budi daya laut (Anonima 2007). Diantara jenis- jenis ikan air tawar yang sekarang sedang dikembangkan dan dibudidayakan adalah ikan Lele dumbo (Clarias gariepinus).

Produksi ikan lele dari tahun ke tahun mengalami peningkatan. Dari sisi budidaya, lele relatif tidak memerlukan banyak perawatan dan memiliki masa tunggu panen yang singkat (Rahayu, 2013).Namun demikian, apabila pembudidayaan ikan lele tersebut tidak diimbangi dengan industri pengolahannya maka upaya tersebu ttidak sinergis, dimana dalam satu waktu panen ikan lele yang berlebih akan menurunkan nilai jualnya karena tidak terbeli oleh masyarakat (Hadiwiyoto, 1993), Untuk itu diperlukan suatu upaya diversifikasi produk olahan ikan lele agar lebih meningkatkan nilai jualnya.

Pengolahan ikan menjadi dendeng merupakan salah satu alternatif penganekaragaman produk yang diharapkan dapat diterima masyarakat untuk memenuhi kebutuhan protein hewani dalam memenuhi kecukupan gizi. 
Dendeng merupakan salah satu produk awetan dari daging. Pada prinsipnya proses pembuatan dendeng adalah merupakan proses pengawetan daging dengan cara pengeringan dengan menambah bahan pengawet (garam, gula, sendawa) dan bahan lain untuk memperoleh rasa yang diinginkan. Beberapa masalah yang sering timbul pada produk dendeng ikan, antara lain: kualitas produk umumnya belum memuaskan. produk mudah hangus karena penggunaan konsentrasi gula jawa yang terlalu tinggi. Selain itu, metode pengeringan belum ada yang tepat untuk menentukan kualitas dendeng yang baik(Dewi, 2006).

Proses pengeringan yang maksimal dan sangat mempengaruhi kualitas dendeng yang dihasilkan. Pengeringan bertujuan untuk mengurangi kadar air dalam bahan pangan sehingga dapat menghambat pertumbuhan mikroorganisme yang dapat menyebabkan kerusakan bahan pangan dan memperpanjang daya simpannya(Nida,dkk. 2014). Penggunaan suhu yang tidak memenuhi standar pemanasan dapat merusak kadar protein yang ada dalam daging dan dapat menurunkan nilai gizi daging. Metode pengeringan cabinet dryer pada daging ikan lele dumbo diharapkan memenuhi standar mutu dari dendeng ikan lele yang dihasilkan. Penelitian ini bertujuan untuk mengetahui pengaruh suhu pengeringan (cabinet dryer) yang berbeda pada daging ikan leledumbo terhadap mutu kimia (kadar air, kadar protein, dan kadar lemak), serta penerimaan panelis terhadap dendeng ikan leledumbo yang dihasilkan.

\section{METODE PENELITIAN}

\section{Rancangan Penelitian}

Rancangan penelitian yang digunakan adalah Rancangan Acak Lengkap (RAL) dengan tiga ulangan. Variabel penelitian yaitu suhu pengering, yaitu suhu pengeringan $60^{\circ} \mathrm{C}, 65^{\circ} \mathrm{C}$, dan $70^{\circ} \mathrm{C}$.

\section{Bahan dan Alat}

Bahan utama yang digunakan dalam penelitian ini adalah ikan lele dumbo (Clarias gariepinus) berukuran panjang $\pm 30 \mathrm{~cm}$ dan bobot sekitar $500 \mathrm{~g}$. Ikan lele dumbo di peroleh dari tempat Budidaya Ikan Air Tawar Makassar. Bahan tambahan (bumbu) untuk pembuatan dendeng ikan adalah garam, gula merah, ketumbar, bawang putih, , merica dan lengkuas. Bahan tambahan tersebut diperoleh dari pasar $\mathrm{Pa}$ Baeng-baeng, Makassar.

Alat-alat yang digunakan dalam penelitian ini meliputi: cabinet dryer, mesin pemisah tulang ikan, pisau, , kaca dengan ketebalan $4 \mathrm{~mm}$, baskom, kompor, sudek, sendok, garpu, penggorengan (wajan), desikator, timbangan digital kapasitas 500 $\mathrm{g} \times 0,019 \mathrm{~g}$, blender, kompor gelas kimia, gas elpiji, cawan porselen, cawan aluminium, labu Kjedhal, selenium, labu lemak, saringan timbel, kertas saring bersih, kondensor, gelas Erlenmeyer, labu ukur, pemanas listrik, Soxhlet, pipetdan alat penyuling.

\section{Prosedur Penelitian}

\section{Pemilihan Ikan Segar}

Ikan lele dumbo segar harus memenuhi karakteristik sebagai berikut: (a) Mata ikan cerah, bola mata menonjol dan kornea jernih; (b) Insang berwarna merah 
cemerlang tanpa lendir (c) Sayatan daging sangat cemerlang; (d) Bau segar; (e) Tekstur padat dan elastis bila ditekan dengan jari.

\section{Pemisahan Tulang}

Ikan lele segar terlebih dahulu disiangi dan dibersihkan. Selanjutnya, daging dipisahkan dari tulang ikan menggunakan mesin pemisah tulang ikan. Proses pemisahan ikan menggunakan mesin lebih efektif dan efisien.

\section{Penimbangan dan pembuatan bumbu}

Persiapan bumbu Semua bumbu dihaluskan, selanjutnya ditimbang berdasarkan berat yang ditentukan.

Tabel 1. Komposisi bumbu

\begin{tabular}{|c|c|c}
\hline No & Bumbu & $\begin{array}{l}\text { Bumbu } \\
\text { (\% berat daging ikan) }\end{array}$ \\
\hline 1 & Gula Merah & 10 \\
\hdashline 2 & Ketumbar & 2 \\
\hdashline 3 & Bawang Putih & 2,8 \\
\hdashline 4 & Garam & 2 \\
\hdashline 5 & Menca & 2 \\
\hdashline 6 & Lengkuas & 2 \\
\hline
\end{tabular}

\section{Pencetakan}

Menuang adonan ke dalam loyang kemudian meratakan hingga ketebalan 4 $\mathrm{mm}$.

\section{Pengeringan}

Memanggang adonan dendeng di dalam cabinet dryer hingga kering menggunakan suhu $60^{\circ} \mathrm{C}, 65^{\circ} \mathrm{C}$ dan $70^{\circ} \mathrm{C}$ selama 8 jam dan dilakukan 3 kali ulangan untuk setiap perlakuan.

\section{Penggorengan}

Dendeng yang telah jadi kemudian digoreng dengan menggunakan deep freyer selama 50 detik dengan suhu $150^{\circ} \mathrm{C}$ sampai dendeng matang, kemudian diangkat dan siap untuk diuji organoleptik.

\section{Analisis Data}

Analisis data yang digunakan untuk mengetahui pengaruh variasi suhu pengering terhadap kadar air, kadar protein, kadar lemak dan uji hedonik adalah analisis sidik ragam yang diolah dengan menggunakan programSPSS IBM(Versi 20). Jika analisis menunjukkan adanya perbedaan yang nyata dari setiap metode pengeringan yang digunakan maka dilanjutkan uji Duncan dengan taraf kepercayaan $95 \%$.

\section{HASIL DAN PEMBAHASAN}

\section{Kadar Air}

Kadar air merupakan salah satu sifat kimia dari bahan yang menunjukkan banyaknya air yang terkandung di dalam bahan pangan. Menurut Hadiwiyoto (1993), menyatakan bahwa air merupakan komponen terbanyak yang terdapat di dalam daging ikan.Kadar air merupakan parameter bahan pangan yang sangat mempengaruhi daya simpan. Hasil pengujian analisis kadar air dendeng ikan lele dumbo dengan suhu bervariasi menggunakan cabinet dryer dapat dilihat pada Gambar 1.

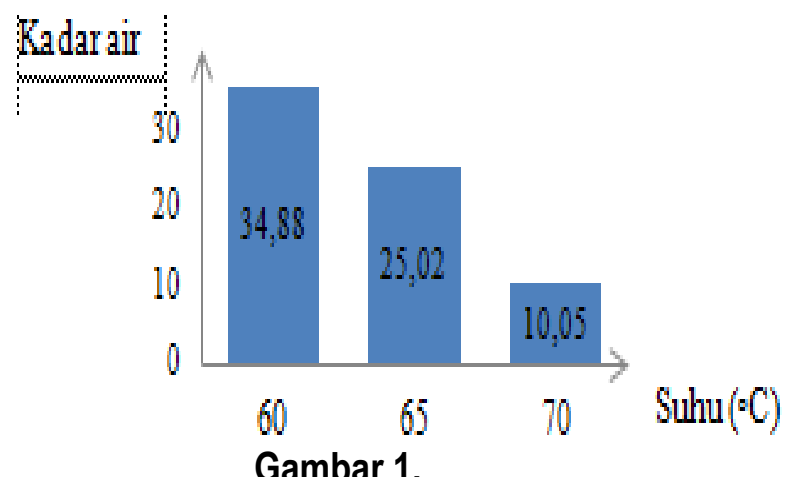

Pengaruh Suhu Pengeringan Terhadap

Kadar Air Dendeng Ikan Lele Dumbo

Kadar air dendeng ikan lele dumbo tertinggi ditunjukkan pada perlakuan suhu pengeringan $60^{\circ} \mathrm{C}$ dan kadar air terendah sebagai perlakuan terbaik ditunjukkan pada perlakuan pengeringan dengan suhu $70^{\circ} \mathrm{C}$, yaitu masing-masing $34,88 \%$ dan 
$10,05 \%$. Perlakuan suhu $70^{\circ} \mathrm{C}$ telah memenuhi standar kadar air dendeng ikan maksimal $12 \%$.

Semakin tinggi suhu pengeringan, maka semakin rendah kadar air suatu bahan pangan. Hal ini disebabkan karena semakin tinggi suhu yang digunakan maka perbedaan kandungan uap air yang ada pada bahan dan udara sekitar akan mengalami perbedaan dengan perbedaan tersebut maka akan menyebabkan adanya penguapan yang cepat. Hal ini sesuai dengan pernyataan Desrosier, (1988) menyatakan bahwa semakin tinggi suhu dan semakin lama waktu pengeringan yang digunakan untuk mengeringkan suatu bahan maka air yang menguap dari bahan akan semakin banyak. Hal ini juga diperkuat dengan pernyataan Riansyah, dkk (2013) yang menyatakan bahwa semakin tinggi suhu dan lamanya waktu pengeringan yang diberikan, memberikan pengaruh yang sangat besar terhadap kecepatan perpindahan air ikan asin sepat siam. Penyataan serupa juga dikemukankan oleh Fitriani (2008), menyatakan semakin tinggi suhu dan lama waktu pengeringan maka semakin banyak molekul air yang menguap dari belimbing kering yang dikeringkan sehingga kadar air yang diperoleh semakin rendah.

\section{Kadar Protein}

Hasil analisis kadar protein dendeng ikan lele dumbo dari berbagai perlakuan (Gambar 2.), Protein tertinggi terdapat pada perlakuan dengan suhu pengeringan $65^{\circ} \mathrm{C}$ yaitu sebesar $16,04 \%$, dan terendah didapatkan pada perlakuan suhu pengeringan $70^{\circ} \mathrm{C}$ yaitu sebesar $13,44 \%$.

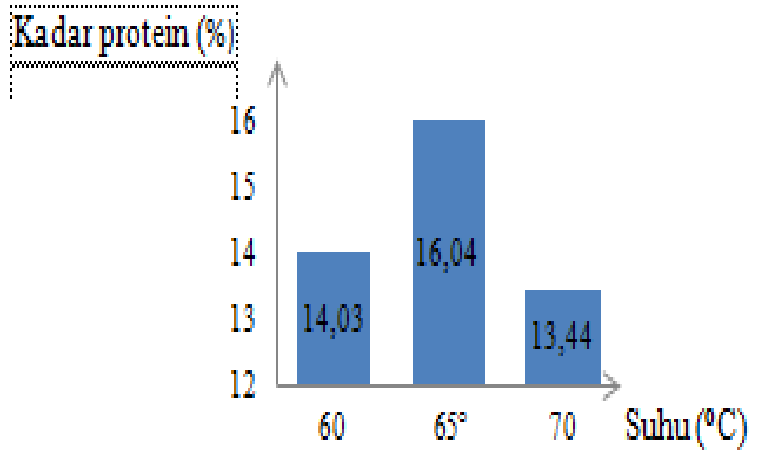

Gambar 2.

Pengaruh Suhu Pengeringan Terhadap Kadar Protein Dendeng Ikan Lele Dumbo

Rendahnya kadar protein pada suhu $70^{\circ} \mathrm{C}$ disebabkan karena pengeringan pada suhu tinggi akan mengakibatkan denaturasi dan degradasi protein serta menurunkan fungsi dari asam amino esensial (Kabaheda dkk, 2009). Pada perlakuan $65^{\circ} \mathrm{C}$ terjadi peningkatan kadar protein namun pada perlakuan $70^{\circ} \mathrm{C}$ terjadi penurunan.

Penurunan ini diduga disebabkan oleh denaturasi protein yang disebabkan oleh suhu pemanasan tinggi. Menurut Sethiyarini (2008), penurunan kadar protein diakibatkan adanya flokuasi yaitu penggunpalan dari partikel yang tidak stabil menjadi partikel yang diendapkan. Flokuasi merupakan tahap awal denaturasi. Denaturasi merupakan suatu perubahan atau modifikasi terhadap struktur sekunder, tersier dan kuartener pada protein tanpa terjadinya pemecahan ikatan kovalen.

Pemanasan menyebabkan protein terdenaturasi. Pada saat pemanasan, panas akan menembus daging dan menurunkan sifat fungsional protein. Pemanasan dapat merusak asam amino dimana ketahanan protein oleh panas sangat terkait dengan asam amino penyusun protein tersebut sehingga hal ini yang menyebabkan kadar protein menurun dengan semakin meningkatnya suhu pemanasan. 


\section{Kadar Lemak}

Hasil pengujian analisis kadar lemak dari berbagai perlakuan dapat dilihat pada Gambar 3. Hasil pengeringan dendeng ikan lele dumbo menggunakan cabinet dryerpada berbagai suhu pengering terhadap kadar lemak menunjukkan bahwa perlakuan suhu pengeringan $70^{\circ} \mathrm{C}$ memiliki kadar lemak tertinggi yaitu $48,92 \%$. Sedangkan perlakuan suhu pengeringan $65^{\circ} \mathrm{C}$ memiliki kadar lemak terendah yaitu $39,54 \%$.

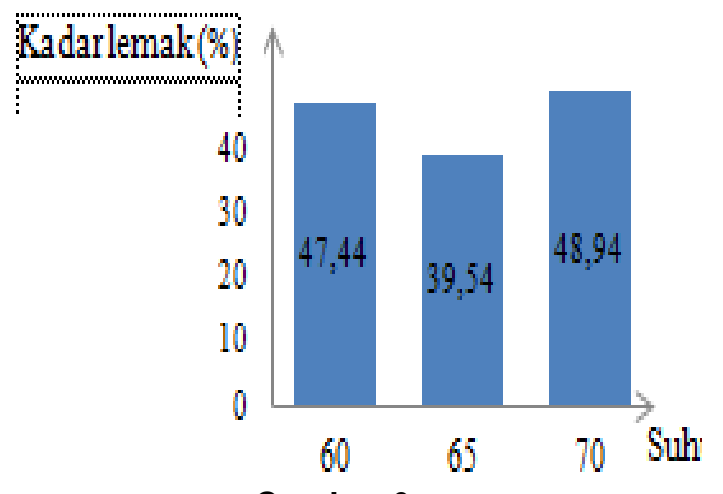

Gambar 3.

Pengaruh Suhu Pengeringan Terhadap Kadar Lemak Dendeng Ikan Lele Dumbo

Menurut pernyataan Soeparno (2011) menyatakan bahwa, variasi komposisi kimia antara kadar lemak dan protein pada daging saling merefleksikan antara satu dengan lainnya dimana apabila kadar protein rendah maka kadar lemak akan tinggi begitu pula sebaliknya. Hal yang sama dikemukakan oleh Rahayu dkk. (1992), mengenai keterkaitan antara kadar air dan kadar lemak, dimana kadar lemak ikan berbanding terbalik dengan kadar airnya. Ikan dengan kandungan lemak yang tinggi biasanya mempunyai kandungan air cenderung lebih rendah. Hal ini sejalan dengan penelitian Zuhra dkk. (2012), menyatakan bahwa meningkatnya kadar lemak dengan suhu pengeringan yang tinggi dapat disebabkan oleh penurunan kadar air sehingga persentase kadar lemak meningkat. Hal serupa dikemukakan oleh Yuniarti (2007), yang menyatakan bahwa dengan lamanya waktu dan tinggi suhu yang digunakan pada proses pengeringan akan menyebabkan kandungan lemak yang ada pada bahan juga semakin meningkat dan kandungan air yang semakin menurun.

\section{Hedonik Warna}

Hasil uji hedonik warna dendeng ikan lele dumbo (Gambar4.) menunjukkan penilaian panelis yang tertinggi terdapat pada perlakuan pengeringan dengan suhu $70^{\circ} \mathrm{C}$ yaitu sebesar 4,00 dengan kriteria suka dan yang terendah yaitu perlakuan suhu $60^{\circ} \mathrm{C}$ sebesar 3,28 dengan kriteria cukup suka.

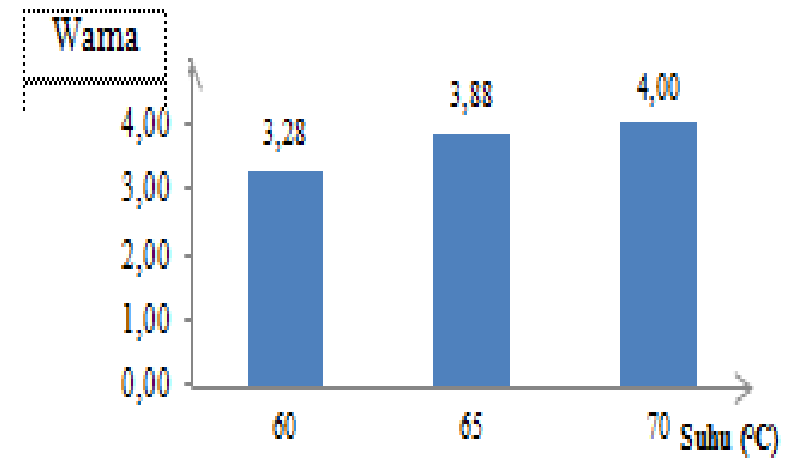

Gambar 4.

Hasil Uji Hedonik Warna Dendeng Ikan Lele Dumbo

Perbedaan penggunaan suhu pengeringan pada dendeng ikan lele dumbo meberikan pengaruh nyata terhadap warna dendeng yang dihasilkan. Berdasarkan hasil uji DMRT menunjukkan bahwa perlakuan $65^{\circ} \mathrm{C}$ dan $70{ }^{\circ} \mathrm{C}$ merupakan perlakuan terbaik dan lebih disukai oleh panelis karena diperoleh dendeng yang berwarna coklat. Warna coklat yang diperoleh disebabkan karena terjadinya reaksi millard pada saat 
pengeringan dengan suhu tinggi pada dendeng ikan tersebut. Menurut Kramlich dkk., 1973 dalam Dadik (2006) Pembentukan warna coklat disebabkan adanya reaksi antara asam amino bebas dari protein atau komponen nitrogen lainnya dengan grup karbonil yang berasal dari gula atau karbohidrat lainnya Menurut Jamhari $d k k, \quad$ (2005) bahwa warna dendeng dapat dipengaruhi oleh suhu yang digunakan dalam proses pengeringan, sejalan dengan pernyataan Lawrie, (1995) bahwasuhu pengeringan juga mempengaruhi warna dendeng, dimana perubahan warna daging yang diolah dipengaruhi oleh lama pengeringan dan suhu pengeringan yang digunakan.

\section{Hedonik Tekstur}

Tekstur Hasil uji hedonik terhadap tekstur dendeng ikan lele dumbo yang dihasilkan dapat dilihat pada Gambar 5 . Tekstur merupakan sekelompok sifat fisik yang ditimbulkan oleh elemen struktural bahan pangan untuk mencapai bentuk rupa, sebagai usaha untuk memberikan tekstur tertentu pada permukaan. Tekstur menjadi salah satu pilihan konsumen untuk memilih suatu produk pangan.

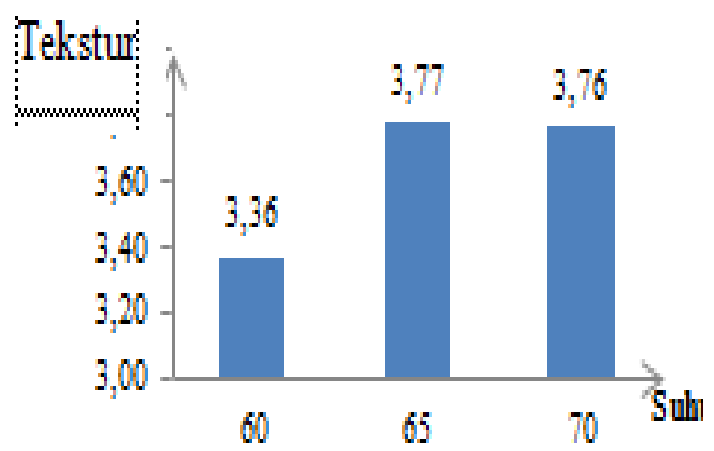

Gambar 5.

Hasil Uji Hedonik Tekstur Dedeng Ikan Lele Dumbo

Pengamatan tekstur dendeng ikan lele dumbo dilakukan secara hedonik oleh
25 panelis dapat diketahui bahwa tingkat kesukaan panelis terhadap tekstur dendeng ikan lele dumbo terbaik yaitu perlakuan suhu pengeringan $60^{\circ} \mathrm{C}$ dan $70^{\circ} \mathrm{C}$ dengan kriteria suka. hal ini disebabkan oleh karena dendeng ikan lele dumbo yang dikeringkan pada suhu $65^{\circ} \mathrm{C}$ dan $70^{\circ} \mathrm{C}$ memiliki kadar air yang rendah sehingga tekstur dendeng lebih renyah. Sesuai dengan penelitian Dadik (2006) mengatakan bahwa semakin rendah kadar air yang terdapat dalam dendeng seiring meningkatnya suhu maka produk dendeng tersebut semakin renyah. Purnomo, (1995) menjelaskan bahwa kadar air dan aktivitas air dalam bahan pangan sangat besar peranannya, terutama dalam menentukan tekstur suatu bahan pangan.

\section{Hedonik Aroma}

Aroma merupakan salah satu faktor penting yang mempengaruhi penerimaan suatu produk olahan perikanan . Hasil uji hedonik terhadap aroma dendeng ikan lele dumbo dapat dilihat pada Gambar 6.

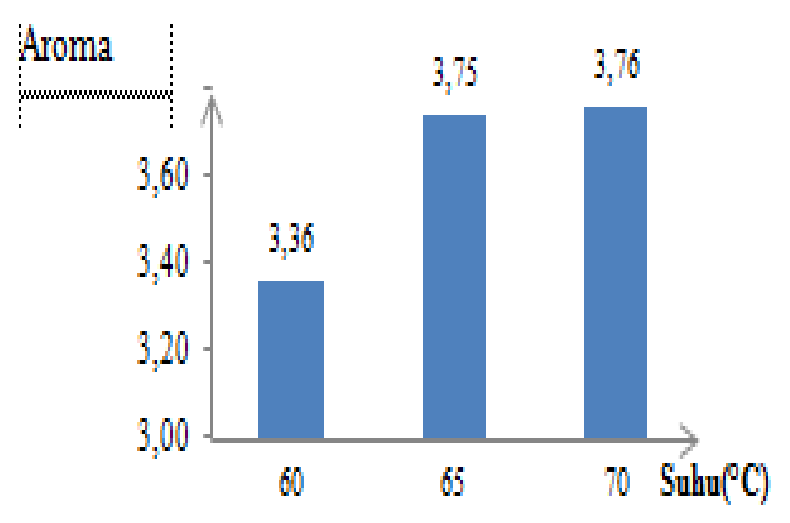

Gambar 6.

Hasil Uji Hedonik Aroma Dendeng Ikan Lele Dumbo

Hasil analisis ragam nilai organoleptik aroma dendeng ikan lele dumbo menunjukkan bahwa perlakuan tidak berpengaruh nyata. Aroma dendeng 
ikan yang dihasilkan hampir sama dari setiap perlakuannya. Hal ini diduga karena aroma dendeng ikan lele yang dihasilkan menggunakan bumbu-bumbu yang beraroma khas seperti aroma ketumbar dan masing-masing perlakuan menggunakan bumbu yang sama. proses pembentukan aroma terjadi pada saat pencampuran bahan (mixing), sampai menjadi bumbu dan akan berlangsung sampai proses pengeringan sehingga terbentuklah aroma khas dendeng (Henny Krissetiana, 2003). Hadiwiyoto (1994) menyatakan bahwa selama pembumbuan dan pengeringan terjadi pembentukan komponen-komponen citarasa, sehingga menambah rasa dan aroma dendeng menjadi lebih khas.

\section{Hedonik Rasa}

Hasil uji hedonik terhadap rasa dendeng ikan lele dumbo dapat dilihat pada Gambar7. Berdasarkan hasil analisis ragam nilai organoleptik rasa dendeng ikan lele dumbo menunjukkan perlakuan berpengaruh nyata dengan nilai organoleptik sebesar 3,25 pada pengeringan suhu $60{ }^{\circ} \mathrm{C}$ artinya cukup disukai oleh panelis sementara pada pengeringan suhu $65 \circ \mathrm{C}$ memiliki nilai sebesar 3,68 yang artinya disukai oleh panelis dan 3,80 pada pengeringan suhu $70{ }^{\circ} \mathrm{C}$ masuk dalam kategori disukai oleh panelis.

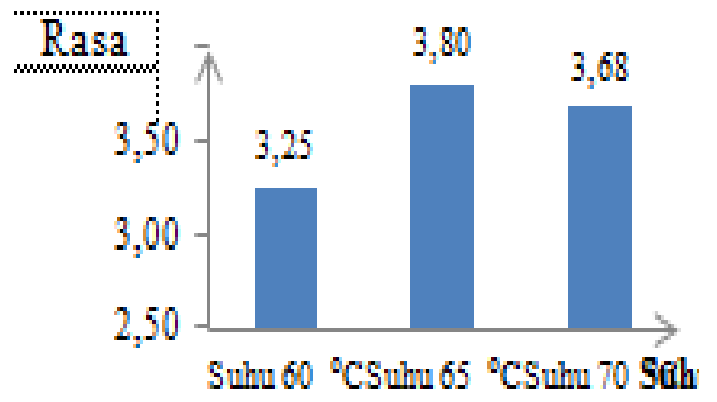

Gambar 7.

Hasil Uji Hedonik Rasa Dendeng Ikan Lele Dumbo
Hasil uji DMRT menunjukkan bahwa pengeringan suhu $65^{\circ} \mathrm{C}$ dan $700^{\circ} \mathrm{C}$ merupakan perlakuan terbaik. Tingginya tingkat kesukaan panelis pada pengeringan suhu $65^{\circ} \mathrm{C}$ dan $70{ }^{\circ} \mathrm{C}$ disebabkan karena menguapnya sebagian besar air sehingga rasa dari dendeng pada perlakuan tersebut lebih enak. Hal ini dapat dinyatakan bahwa suhu pengeringan dan jumlah kadar air dapat mempengaruhi tingkat kesukaan panelis terhadap dendeng ikan lele dumbo yang dihasilkan, seperti halnya pada uji hedonik tekstur . berdasarkan hasil diatas dapat dinyatakan bahwa semakin tinggi suhu akan menurunkan kadar air dari dendeng ikan lele dumbo maka nilai kesukaannya terhadap rasa dari dendeng ikan lele dumbo tersebut semakin baik. Menurut penelitian yang dilakukan oleh Adel Tuyu $d k k .,(2014)$ yang menyatakan bahwa menurunnya kadar air mempengaruhi tingkat kesukaan panelis pada ikan selar asin karena berkurangnya kadar air sehingga komponen penyusun rasa akan keluar .Winarno (2004), menyatakan bahwa rasa dipengaruhi oleh beberapa faktor yaitu senyawa kimia, suhu, konsentrasi dan interaksi dengan komponen rasa yang lain.

\section{KESIMPULAN}

Berdasarkan hasil penelitian dapat ditarik kesimpulan sebagai berikut :

1. Hasil penelitian menunjukkan bahwa penggunaan pengering cabinet dryer dengan berbagai variasi suhu berpengaruh terhadap mutu kimia dendeng ikan lele dumbo yang dihasilkan, dimana suhu pengeringan terbaik adalah suhu $65^{\circ} \mathrm{C}$, dengan kadar air sebesar 25,02\%, kadar protein sebesar $16,04 \%$ dan kadar lemak sebesar $39,54 \%$. 
2. Pada uji hedonik dendeng ikan lele dumbo menunjukkan perlakuan suhu pengeringan berpengaruh terhadap warna, tekstur, dan rasa namun tidak berpengaruh tarhadap aromadendeng yang dihasilkan. Perlakuan terbaik adalah pengeringan suhu $65^{\circ} \mathrm{C}$ karena memiliki nilai yang disukai oleh panelis baik pada warna, tekstur, aroma dan rasa serta memiliki kandungan protein yang tinggi dan kadar air yang cukup rendah.

\section{DAFTAR PUSTAKA}

Adel tuyu, Hens Onibala, Daisy M. Makapedua. 2014. Studi lama pengeringan ikan selar(Selaroides sp) asin dihubungkan dengan kadar air dan nilai organoleptik. Jurnal media teknologi hasil perikana, (on line), vol.2, nomor. 2, (http://martinac1b111003.blogspot.c o.id, diakses tanggal 13 Maret 2016)

Angga Riansyah, Agus Supriadi*, Rodiana Nopianti., 2013. Pengaruh Perbedaan Suhu Dan Waktu Pengeringan Terhadap Karakteristik Ikan Asin Sepat Siam (Ttrichogaster Pectoralis) Dengan Menggunakan Oven. Program Studi Teknologi Hasil Perikanan Fakultas Pertanian Universitas Sriwijaya Indralaya Ogan Hilir.

Anonima. 2007. Departemen Kelautan dan Perikanan. FAO Dorong Pembangunan Perikanan Budidaya. www.dkp.go.id. Diakses 29 Mei 2015

Dadik. 2006. Pengaruh Waktu Curing (Perendaman Dalam Larutan Bumbu) Terhadap Mutu Dendeng Fillet Ikan Lele Dumbo (Clarias
Gariepinus) Selama

Penyimpanan.Skripsi tidak diterbitkan. Bogor: Departemen IImu dan Teknologi Pangan, Fakultas Teknologi. Pertanian, Institut Pertanian Bogor

Desrosier,W.N., $1988 . \quad$ Teknologi Pengawetan Pangan.Diterjemahkan oleh M. Muljoharjo .UI-Pres, Jakarta.

Dewi, E, N. . 2008. Pengaruh Jenis Gula Pada Proses Pengolahan Dendeng Ikan Nila Merah Terhadap Mutu. Jurnal Sanitek Perikanan, (on line) jilid 2, nomor 1 , (http://eprints.undip.ac.id), diakses 17 Mei 2015)

Hadiwiyoto, S. 1993. Teknologi Pengolahan Hasil Perikanan. Liberty, Yogyakarta.

Hadiwiyoto, S. 1994. Studi pengolahan dendeng dengan oven pengering rumah tangga. Buletin Peternakan. $18: 119-126$

Jamhari, E. Suryanto, dan Soeparno. 2005. Karakteristik organoleptik dendeng dari daging kambing bligon yang diberi pakan daun pepaya ( carica papaya) berbagai level. Buletin peternakan 29 (3) 115-121.

Kabahenda, MK., Omony P., Husken SMC. 2009. Post-harvest handling of lowvalue fish products and threats to nutritional quality: a review of practices in the Lake Victoria region www.worldfishcenter.org. Diakses pada 3 November 2015.

Kurnia A. 2006. Saatnya Indonesia Menerapkan Budidaya Ikan Ramah Lingkungan.

http://www.beritaiptek.com . diakses tanggal 6 Juni 2015. 
Lawrie, R. A. 1995. Ilmu Daging. Edisi Kelima. Penterjemah Aminuddin Parakkasi dan Yuda Amwila.

Nida, Asmawati, Gunawan,S. 2014. Dendeng Ikan Leubiem (Canthidermis Maculatus) Dengan Variasi Metode Pembuatan, Jenis Gula, Dan Metode Pengeringan. Jurnal Teknologi dan Industri Pertanian Indonesia, (ON line) jilid $6 \quad$ Nomor 3, (http://www.jurnal.unsyiah.ac.id,diak ses 11 Juni 2015)

Purnomo, H dan Adiono. 1987. IImu Pangan. Ul. Jakarta.

Rahayu, S. 2013. Budidaya Lele di Lahan Sempit. Sidoarjo: Infra Pustaka.

Rahayu, W. P., S. Ma'oen, Suliantari dan S. Fardiaz. 1992. Teknologi Fermentasi Produk Perikanan. PAU Pangan Gizi. Institut Pertanian Bogor. Bogor.

Sethiyarini. 2008. Pengaruh Suhu dan Lama Pemanasan dengan Menggunakan Ekstraktor Vakum Terhadap Kualitas dan Rendemen Crude Albumin Ikan Gabus (Ophiocephalus striatus) dari Perairan Madura. Skripsi. Fakultas Perikanan. Universitas Brawijaya. Malang

Soeparno. 2005. IImu dan Teknologi Daging. Gajah Mada University Press, Yogyakarta.

Winarno F G. 2004. Kimia Pangan dan Gizi.Jakarta: PT Gramedia.

Zuhra, S. dan C. Erlina. 2012. Pengaruh kondisi operasi alat pengering semprot terhadap kualitas susu bubuk jagung. Jurnal Rekayasa Kimia dan Lingkungan. Vol 9. No. 1 Hal. 36 - 44. Jurusan Teknik Kimia,
Fakultas Teknik, Universitas Syiah Kuala. 